\title{
The Role of Reaction Engineering in Bioprocess Development
}

\author{
Udo Kragl ${ }^{\star a b}$
}

\begin{abstract}
This short review highlights the role of reaction engineering as a tool for bioprocess development. Selected examples are discussed that demonstrate the need to understand thermodynamic and kinetic properties of the reaction system in order to identify potential bottlenecks. For coupled enzyme systems and reaction cascades modelling as well as selection of suitable reactor configurations is discussed. For the problem of overcoming product inhibition examples are given, followed by selected examples for in situ product removal. Finally, two reactor concepts for oxidation reactions requiring oxygen are briefly presented.
\end{abstract}

Keywords: Enzyme cascade $\cdot$ in situ product removal $\cdot$ Membrane $\cdot$ Microreactor $\cdot$ Modelling

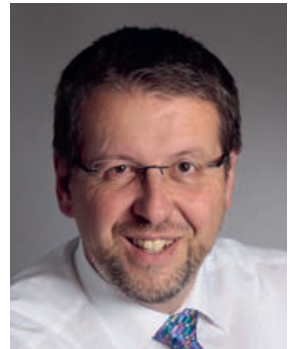

Udo Kragl, born in 1961, studied chemistry at the University of Bonn. He finished his $\mathrm{PhD}$ thesis in 1992 in the field of biochemical reaction engineering. After a postdoc at Ciba-Geigy International Research Laboratories in Takarazuka in Japan, he returned to the Juelich Research Center and University of Bonn for his habilitation. Having finished, he immediately gained a position as full professor for Industrial Chemistry at the University of Rostock. From 2007 to 2015, he was the Dean of the Faculty for Interdisciplinary Research at the University of Rostock. Currently, he is Vice-Rector for Research and Knowledge Transfer at the same university. He taught industrial chemistry at National University Singapore, within the scope of a visiting professorship in 2007. He is active in the German Society of Catalysis (GeCats) and currently chairman of the executive board. His research interests are in the field of biocatalysis, the application of ionic liquids and membrane processes for downstream processing and catalyst recycling, and more recently in biomedical engineering.

\section{Introduction}

Over the last four decades biocatalysts have paved their way into many areas of industrial production processes as well as become valuable tools in lab synthesis. The utilization of such molecules range from high value added pharmaceuticals over ingredients for food technology to commodities such as acrylamide. There is a vast number of reviews and research articles describing the progress over the years. Table 1 lists a selection starting from an early one written by George M. Whitesides and Chi-Hey Wong, who belong to the pioneers introducing enzyme catalysis into organic synthesis. Others have been written by well-known scientists in this area such as Christian Wandrey, Roger Sheldon, Uwe Bornscheuer, Nick Turner or Pedro Lozano, to name just a few. A number of books has been published as well. Kurt Faber's textbook 'Biotransformations in Organic Synthesis' just appeared in its seventh edition. ${ }^{[10]}$
Table 1. Selected reviews on the potential of biocatalysis

\begin{tabular}{|l|l|l|}
\hline Authors & Topic & Ref. \\
\hline Whitesides, Wong & $\begin{array}{l}\text { Enzymes as catalyst in } \\
\text { organic chemistry }\end{array}$ & {$[1]$} \\
\hline $\begin{array}{l}\text { Schmid, Dordick... } \\
\text { Witholt }\end{array}$ & Industrial biocatalysis & {$[2]$} \\
\hline $\begin{array}{l}\text { Liese, Seelbach, } \\
\text { Wandrey }\end{array}$ & Industrial biotransformations & {$[3]$} \\
\hline $\begin{array}{l}\text { Bornscheuer, } \\
\text { Huismann,...Robins }\end{array}$ & Third wave of biocatalysis & {$[4]$} \\
\hline $\begin{array}{l}\text { Wenda, Illner, Mell, } \\
\text { Kragl }\end{array}$ & \begin{tabular}{l} 
Industrial biotechnology \\
\hline $\begin{array}{l}\text { Hönig, Sondermann, } \\
\text { Turner, Carreira }\end{array}$
\end{tabular} & $\begin{array}{l}\text { Retrosynthesis and } \\
\text { biocatalysis }\end{array}$ \\
\hline $\begin{array}{l}\text { Carrea, Ottolina, } \\
\text { Riva }\end{array}$ & $\begin{array}{l}\text { Organic solvents and enzyme } \\
\text { selectivity }\end{array}$ & {$[7]$} \\
\hline Sheldon, Woodley & $\begin{array}{l}\text { Biocatalysis in sustainable } \\
\text { chemistry }\end{array}$ & {$[8]$} \\
\hline $\begin{array}{l}\text { Villa, Alvarez,... } \\
\text { Lozano }\end{array}$ & $\begin{array}{l}\text { Ionic liquids and enzyme } \\
\text { catalysis }\end{array}$ & {$[9]$} \\
\hline
\end{tabular}

Progress has been made over the years in many areas. Novel enzymes were identified first by conventional screening methods and then later by the tools of genetic engineering, rational design and directed evolution, for which Francis H. Arnold was awarded the Nobel price in 2018. ${ }^{[11]}$

However, the biocatalyst - either an enzyme or a whole cell is only part of the whole bioprocess. Already Whitesides and Wong stated in their review: "We note explicitly that the area of enzymatic catalysis in organic synthesis is, as are most areas of practical catalysis, fundamentally a process chemistry."[1] Only 
when all aspects are considered can a successful process be implemented. Catalyst development, reaction engineering and unit operations together will result in cost effective and scalable processes. The earlier the different aspects and their interplay are considered the better.

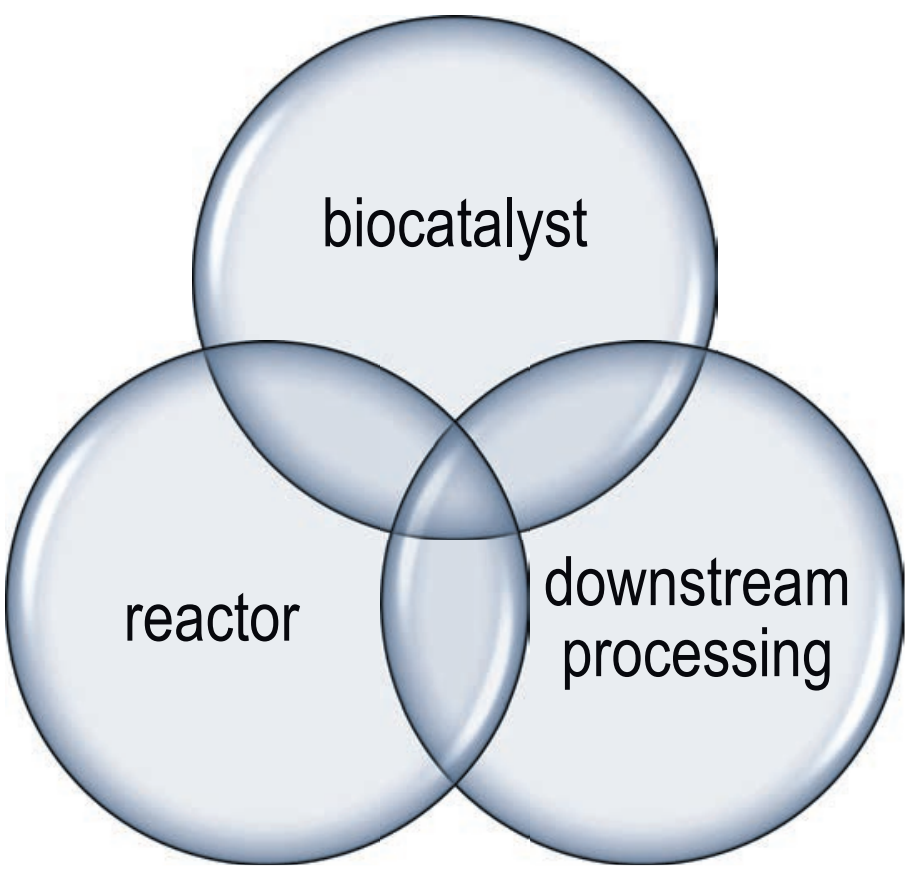

Fig. 1. Elements of process design - simultaneous consideration of different elements will result in an economic and cost competitive bioprocess

Removing a special buffer salt needed for enzyme stabilization at a later stage may become difficult. Removal of enzymes either as soluble macromolecules by membrane filtration or immobilized on a support has never really been an issue, even in continuously operated reactors. Enzyme stability may be improved by modern methods of directed evolution. Together with cost-effective fermentation technologies the product-specific catalyst costs are nowadays not necessarily the limiting factor. The low substrate and as a result low product concentration may be a challenge, not only when water is used as reaction medium. Molecular organic solvents as well as novel types such as ionic liquids have been successfully introduced in the last decades as well. As in all catalytic processes the equilibrium conversion and therefore the yield which can be reached, is limited by the thermodynamics of the reaction. Only a careful analysis of thermodynamic and kinetic properties of the reaction system will reveal possible bottlenecks. To overcome these limitations, in situ product removal has been introduced as one possible tool. Despite many interesting examples this is still an area of intensive research and many interesting approaches.

In the following section several examples are given, where available tools of reaction engineering have been used to improve the process remarkably. A detailed guidebook including basics in enzyme kinetics as well as basics of reactor types such as the batch reactor, continuously operated stirred tank reactor or plug flow reactor was published in $2002,{ }^{[12]}$ following a reduced version in 1999.[13]

\section{Examples}

\subsection{Enzyme Cascades and Side Reactions}

Multi-enzyme cascades have been developed as a tool to overcome the need for isolation of intermediates, to regenerate cofactors or to shift equilibria by further converting an un- wanted side product.[14] Early examples are the enzyme- or substrate-coupled regeneration of redox cofactors ${ }^{[15]}$ or the twostep enzymatic synthesis of $N$-acetylneuraminic acid from cheap $\mathrm{N}$-acetylglucosamine, the monomer of chitin. ${ }^{[16]}$ For all such systems the amount of the individual enzymes has to be determined carefully in order to reach high yields and productivities on one hand, but to minimize the product-specific enzyme costs on the other. The situation is more complex as the enzyme activity has to be considered under operating conditions, which might be different from activity measurement. These are normally performed under initial rate conditions and in the absence of products. ${ }^{[12]}$ Several examples by Wandrey and coworkers address the enzymecoupled cofactor regeneration of $\mathrm{NADH}+\mathrm{H}^{+}$. Also, reduction of the amount of the expensive cofactor as well as of the enzymes is possible on the basis of a kinetic model of the whole reaction system including comparison of different reactor setups. ${ }^{[15]}$

For the two-step enzymatic synthesis of $N$-acetylneuraminic acid, a model describing the complete reaction course was developed based on detailed kinetic investigations. Operating windows were calculated for various enzyme ratios and levels of the starting materials. The optimization took also into account the requirements of downstream processing, catalyst consumption and reaction time. As a result, a fed-batch process was implemented that increased the volumetric productivity two-fold reaching about 24 $\mathrm{g} /(\mathrm{Lxd}) \cdot{ }^{[17]}$

Another early example is the suppression of parallel or consecutive reactions making use of different concentration profiles in batch or plug flow reactors on one hand and a continuously operated stirred tank reactor at the other hand. An early and still impressive example is the suppression of a non-specific side reaction yielding the racemate in the enzymatic addition of hydrogen cyanide to aldehydes and ketones. With simultaneous retention of the enzyme by an ultrafiltration membrane $(R)$-mandelonitrile could be produced at a volumetric productivity of $24 \mathrm{~kg} /(\mathrm{Lxd})$ with an enantiomeric excess of $>99 \%$. ${ }^{[18]}$

More recently the use of reaction compartments limiting the available substrate concentration have been described. However, for a scale-up the resulting mass transfer limitations have to be studied in more detail.[19] The enzymatic synthesis of GDP-Man is a further example where a continuously operated reactor offers advantages over simple batch systems. Starting with a single continuously operated stirred tank reactor (CSTR) the problem of strongly changing enzyme activity with varying substrate concentrations could be solved. ${ }^{[20]}$ The strong product inhibition could be partly overcome by applying a two-stage CSTR-cascade. By this the product specific enzyme consumption could be reduced to 0.9 $\mathrm{U} / \mathrm{g}_{\text {product }}$, which is only $15 \%$ of that in a batch reactor and $45 \%$ of that of a single CSTR. The soluble enzyme was retained by an ultrafiltration membrane.

The last example discussed here is the dynamic kinetic resolution of amino acid derivatives. The in situ racemization is achieved via an organo-catalyst, whereas a protease is performing the kinetic resolution. ${ }^{21]}$ Simple modelling was used to optimize the ratio of the catalysts and to get insight into deactivation scenarios of the two catalysts. In addition, different reactor configurations were investigated.

\subsection{Integrated Product Removal}

Enzyme catalysis is often prone to product inhibition. In very severe cases this may make a reaction useless especially when aiming at higher product concentrations. One option now available is the use of directed evolution or other tools to modify the enzyme itself as outlined in the introduction. Applying other tools of reaction engineering such as integrated product removal offer additional benefits as it could shift non-favorable equilibrium positions. This area is gaining increasing attention as reaction systems are developed where not the biocatalytic step is limiting but 
the thermodynamic equilibrium. Examples have been reviewed recently. ${ }^{[22]}$ For systems with different solubility of substrates and products there are many examples in literature. Co-workers from Eli Lilly used a polystyrene resin to adsorb the product in the stereoselective reduction of ketones using a whole cell biocatalyst.[23] The hydrophobic resin at the same time also acted as substrate reservoir for the hydrophobic substrate. Thus, the biocatalysts only saw a very low saturation concentration in the aqueous system well below $5 \mathrm{mmol} / \mathrm{L}$. Due to the size of the cells and the resin an easy separation is possible. The overall productivity in a $300 \mathrm{~L}$ reactor was about $75 \mathrm{~g} /(\mathrm{Lxd})$. Especially lipases can be very easily used with aqueous/organic two-phase systems. For kinetic resolution of ethyl 2-hydroxy-4-phenylbutyrate a membrane reactor was developed for continuous removal of the strongly inhibiting product. ${ }^{[24]}$ The reaction is performed in a heptane/buffer emulsion. The water phase is continuously removed by means of a hydrophilic ultrafiltration membrane lowering the concentration of the inhibiting acid well below $100 \mathrm{mmol} / \mathrm{L}$. As a result, the time to reach full conversion could be reduced down to $30 \%$ resulting in a volumetric productivity up to $275 \mathrm{~g} /(\mathrm{Lxd})$.

These examples demonstrate possible approaches when the solubility of the reactants shows large differences in different solvents. This might become more difficult when water-soluble compounds are part of the reaction system or all reactants show only low solubility. For the later case, Liese and co-workers recently described the use of a reactive rectification for a kinetic resolution. ${ }^{[25]}$ The enzyme is immobilized in catalytic packings in a column. The equilibrium of the transesterification reaction is shifted to the product side by removal of the low boiling $(S)-2$ pentanol as target product.

For compounds that are easily soluble in water either reactive extraction or in situ crystallization might be suitable approaches. For the already discussed synthesis of $\mathrm{N}$-acetylneuraminic acid a reactive extraction with trioctylmethylammonium chloride was developed.[26] However, the selectivity between the carbohydrates in solution was not very high. Simulations showed that a batch process with continuous removal of the organic phase is feasible, but the productivity of the whole reaction system could be only slightly improved. More success was reported for the application of in situ product crystallization in biocatalytic processes. [27] Options are the direct product crystallization due to its low solubility, or the addition of an additive for an induced in situ product crystallization. The later has been successfully introduced for shifting the reaction equilibria of selective transaminase-catalyzed reactions. ${ }^{[28]}$ For a range of tested substrates, the yield was typically between 4 and $37 \%$, even with a two-fold excess of the donor amine. By addition of 3,3-diphenylpropionic acid for in situ product crystallization the yield of the formed chiral amines could be raised three- to four-fold to well over $70 \%$, without any loss of the perfect enantioselectivity of the transaminase.

\subsection{Oxygen Transfer}

The last two examples deal with tools for oxygenation of enzymatic reactions. However, the same tools and reactor concepts might be used for delivery or removal of other gases as well. In the first example a bubble-free aeration through a silicone tube is achieved. ${ }^{[29]}$ Laccases can be used for a range of interesting reaction ranging from wastewater treatment to C-N-heterocoupling. Oxygen is needed as oxidation reagent and can be delivered through a thin-walled silicon tubing avoiding enzyme deactivation at gas-liquid interfaces caused by conventional bubbling of air into a solution. Together with a simple kinetic model, different reactor configurations and the required aeration rate and therefore tube length could be calculated. Very high oxygen transfer rates can be achieved in micro-structured reactors. ${ }^{[30]}$ For the oxidation of glucose with glucose oxidase a falling film microreactor was used. Compared to a conventional bubble column the oxygen transfer rate could be increased almost 100 -fold yielding in $\mathrm{k}_{\mathrm{L}} \mathrm{a}$ values of about $20500 \mathrm{1} / \mathrm{h}$. Together with a very short residence time of about 26 seconds a very high volumetric productivity of $18.7 \mathrm{~kg} /(\mathrm{Lxd})$ was achieved at $30 \%$ conversion.

\section{Conclusions}

Nowadays it seems possible to design new biocatalysts for more or less any given reaction, at the latest since the pioneering work of Frances Arnold and others. However, to go from the synthesis of a few milligram to a gram- or even kilogram-scale synthesis, other toolboxes and a thorough understanding of the reaction system are required. Otherwise possible bottlenecks will not be identified. Several years ago, in addition to the wellknown principles of green chemistry published by Anastas and Warner, ${ }^{[31]}$ Neil Winterton asked in his "twelve more green chemistry principles" to "establish a full mass balance for process", to "investigate basic thermochemistry" and "to consult a chemical or process engineer". ${ }^{[32]}$ Of course, this holds for all types of (catalytic) reactions. But it also requires that some of the basic knowledge should be taught in this context to make a potential user aware what she or he may accomplish using the right tools together with a novel biocatalyst from the very beginning.

\section{A Very Personal Acknowledgement}

I got to know Oreste Ghisalba when I started my $\mathrm{PhD}$ thesis at the Research Center in Juelich. Together with his group we developed a large-scale synthesis of $N$-acetylneuraminic acid and other related compounds as building blocks for glycotechnology. As a result, a toolbox of various methods was developed, and we learned a lot about the pitfalls in scaling up to a kg-range. I am very grateful to Oreste as he arranged for my stay as postdoc at the International Research Laboratories of Ciba-Geigy in Takarazuka, Japan. Over the years, we met at various places all over the world and had very stimulating and intense discussions about science and other important things of life.

\section{Acknowledgements}

I am indebted to many co-workers and co-operation partners over the past decades who have contributed to or inspired our work. Funding from public sources such as DFG, various federal ministries as well as the local government and University of Rostock is gratefully acknowledged, as well as from a number of companies and the Fonds der Chemischen Industrie.

[1] G. M. Whitesides, C.-H. Wong, Angew. Chem. Int. Ed. 1985, 24, 617

[2] A. Schmid, J. S. Dordick, B. Hauer, A. Kiener, M Wubbolts, B. Witholt, Nature 2001, 409, 258

[3] A. Liese, K. Seelbach, C. Wandrey, 'Industrial Biotransformations', $2^{\text {nd }}$ ed., Wiley-VCH, 2006.

[4] U. T. Bornscheuer, G. W. Huismann, R. J. Kazlauskas, S. Lutz, J. C. Moore, K. Robins, Nature 2012, 485, 185.

[5] S. Wenda, S. Illner, A. Mell, U. Kragl, Green Chem. 2011, 13, 3007.

[6] M. Hönig, P. Sondermann, N. J. Turner, E. M. Carreira, Angew. Chem. Int. Ed. 2017, 56, 8942.

[7] G. Carrea, G. Ottolina, S. Riva, Trends Biotechnol. 1995, 13, 63

[8] R. A. Sheldon, J. M. Woodley, Chem. Rev. 2018, 118, 801.

[9] R. Villa, E. Alvarez, P. Porcar, E. Garcia-Verdugo, S. V. Luis, P. Lozano, Green Chem. 2019, 21, 6527.

[10] K. Faber, 'Biotransformations in Organic Chemistry', Springer, 2018.

[11] F. H. Arnold, Angew. Chem. Int. Ed. 2018, 57, 4143.

[12] M. Biselli, U. Kragl, C. Wandrey, 'Reaction Engineering for EnzymeCatalyzed Biotransformations', in 'Enzyme Catalysis in Organic Synthesis', $2^{\text {nd }}$ ed., Eds. K. Drauz, H. Waldmann, Wiley-VCH, 2002.

[13] U. Kragl, A. Liese, 'Biotransformations, Engineering Aspects', in 'Encyclopedia of Bioprocess Technology: Fermentation, Biocatalysis \& Bioseparation', Eds. M. C. Flickinger, S. W. Drew, John Wiley \& Sons, 1999.

[14] S. Gandomkar, A. Zadlo-Dobrowolska, W. Kroutil, ChemCatChem 2019, $11,225$.

[15] U. Kragl, W. Kruse, W. Hummel, C. Wandey, Biotechnol. Bioeng. 1996, 52, 309. 
[16] U. Kragl, D. Gygax, O. Ghisalba, C. Wandrey, Angew. Chem. Int. Ed. Engl. 1991, 30, 827 .

[17] V. Zimmermann, H.-G. Hennemann, T. Daußmann, U Kragl, Appl. Microbiol. Biotechnol. 2007, 76, 597.

[18] U. Kragl, U. Niedermeyer, M.-R. Kula, C. Wandrey, Ann. N. Y. Acad. Sci. 1990, 613, 167.

[19] a) P. Bracco, H. Busch, J. von Langermann, U. Hanefeld, Org. Biomol. Chem. 2016, 14, 6375; b) J. von Langermann, S. Wapenhensch, Adv. Syn. Catal. 2014, 356, 2989.

[20] S. Fey, L. Elling, U. Kragl, Carbohydr. Res. 1997, 305, 475

[21] V. Zimmermann, M. Beller, U. Kragl, Org. Proc. Res. Develop. 2006, 10 622.

[22] a) M. Bechtold, S. Panke, Chimia 2009, 63, 345; b) J. T. Dafoe, A. J. Daugulis, Biotechnol. Lett. 2014, 36, 443.

[23] J. T. Vicenzi, M. J. Zmijewski, M. R. Reinhard, B. E. Landen, WE. L. Muth, P. G. Marler, Enz. Microbiol Technol. 1997, 20, 494.

[24] A. Liese, U. Kragl, H. Kirkels, B. Schulze, Enz. Microbiol. Technol. 2002, 30,673 .

[25] S. Kühn, G. Sluyter, M.-A. Christlieb, R. Heils, A. Stöbener, J. Kleber, I. Smirnova, A. Liese, Ind. Eng. Chem. Res. 2017, 56, 6451.

[26] V. Zimmermann, I. Masuck, U. Kragl, Sep. Pur. Tech. 2008, 63, 129.
[27] D. Hülsewede, L.-E. Meyer, J. von Langermann, Chem. Eur. J. 2019, 25, 4871.

[28] D. Hülsewede, M. Tänzler, P. Süss, A. Mildner, U. Menyes, J. von Langermann, Eur. J Org. Chem. 2018, 2130.

[29] R. Pilz, E. Hammer, F. Schauer, U. Kragl, Appl. Microbiol. Biotechnol. 2003, 60, 708 .

[30] S. Illner, C. Hofmann, P. Löb, U. Kragl, ChemCatChem 2014, 6, 1748.

[31] P. T. Anastas, J. C. Warner, 'Green Chemistry: Theory and Practice', Oxford University Press, 1998.

[32] N. Winterton, Green Chem. 2001, G73, DOI: 10.1039/b110187k

License and Terms

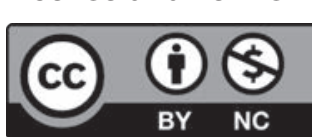

This is an Open Access article under the terms of the Creative Commons Attribution License CC BY_NC 4.0. The material may not be used for commercial purposes.

The license is subject to the CHIMIA terms and conditions: (http:// chimia.ch/component/sppagebuilder/?view=page \&id=12).

The definitive version of this article is the electronic one that can be found at doi:10.2533/chimia.2020.378 